\title{
KONFERENCJA NAUKOWA „W KRĘGU BADAŃ NAD POLONIĄ I DUSZPASTERSTWEM POLONIJNYM", LUBLIN 7 V 2014
}

Jednym z procesów wyraźnie zauważalnych we współczesnej Polsce są silne prądy emigracyjne. Jest to zjawisko o charakterze nie tylko społecznym i ekonomicznym, ale również kulturowym i religijnym. Coraz więcej Polaków opuszcza rodzinny kraj, na obczyźnie szukając godziwych warunków życia i pracy. W parze z tym swoje posłannictwo realizuje Kościół, zapewniający duszpasterską troskę o Polonię. Refleksji na ten temat poświecona została konferencja naukowa zorganizowana w środę, 7 maja 2014 r. na Katolickim Uniwersytecie Lubelskim Jana Pawła II. Jej tytuł brzmiał: „W kręgu badań nad Polonią i duszpasterstwem polonijnym. Istota i metodologia badań polonijnych".

Konferencję zorganizowały: Ośrodek Badań nad Polonią i Duszpasterstwem Polonijnym Katolickiego Uniwersytetu Lubelskiego Jana Pawła II oraz Sanktuarium Matki Bożej Królowej Świata - Opiekunki Ludzkich Dróg w Sokołowie Małopolskim. Spotkanie naukowe odbyło się w gmachu Biblioteki Uniwersyteckiej KUL w Lublinie, w Czytelni Teologiczno-Filozoficznej. Honorowego patronatu udzielili temu wydarzeniu: Metropolita Przemyski ob. łac. i Przewodniczący Konferencji Episkopatu Polski w latach 2004-2014 abp Józef Michalik, Przewodniczący Komisji Konferencji Episkopatu Polski ds. Polonii i Polaków za Granicą i Delegat Komisji Episkopatu Polski ds. Duszpasterstwa Emigracji Polskiej bp Wiesław Lechowicz oraz Rektor Polskiej Misji Katolickiej we Francji ks. infuł. Stanisław Jeż. Partnerami organizatorów zostały: Instytut Leksykografii KUL oraz Biblioteka Uniwersytecka KUL ${ }^{1}$.

Głównym inicjatorem i koordynatorem konferencji był pracownik naukowy Ośrodka Badań nad Polonią i Duszpasterstwem Polonijnym KUL ks. dr Sławomir Zych. Program spotkania naukowego obejmował wygłoszenie aż 26 referatów

${ }^{1}$ M. Nabożny, W kręgu badań nad Polonia i duszpasterstwem polonijnym, „Niedziela”, 18 (2014) s. 34. 
i komunikatów, w czterech sesjach. Do grona prelegentów zaproszeni zostali reprezentanci różnych uczelni wyższych i instytucji życia kulturalnego z kraju i zagranicy, a także środowisk teologicznych z Włocławka i Krakowa. Słuchaczami poszczególnych wykładów było kilkadziesiąt osób. Byli to przede wszystkim pracownicy naukowi i studenci, ale również pasjonaci historii i osoby żywo zainteresowane tematyką emigracyjną i polonijną. Wydarzeniu towarzyszyła obecność kopii wizerunku Pani Sokołowskiej - Patronki emigrantów.

Otwarcia spotkania dokonał ks. dr Sławomir Zych. Jak nadmienił na wstępie: „Przypadł mi w udziale zaszczyt pełnienia funkcji koordynatora tej konferencji naukowej. Czynię to niejako w dwóch aspektach: jako pracownik Ośrodka Badań nad Polonią i Duszpasterstwem Polonijnym KUL oraz opiekun naukowy sanktuarium Matki Bożej Opiekunki Ludzkich Dróg w Sokołowie Małopolskim z ramienia Biskupa Rzeszowskiego". Przekazał on obecnym pozdrowienia od metropolity przemyskiego abpa Józefa Michalika, ordynariusza rzeszowskiego bpa Jana Wątroby i bpa Wiesława Lechowicza. Przywitał też przybyłych gości oraz wszystkich prelegentów.

Następnie miejsce miały okolicznościowe przemówienia. Pierwsza zabrała głos dr Anna Łucka z Rady Polskiej Misji Katolickiej we Francji: „W imieniu ks. infuł. Stanisława Jeża, Rektora Polskiej Misji Katolickiej we Francji i swoim własnym chciałabym przekazać najserdeczniejsze pozdrowienia oraz wyrazy uznania za ogrom pracy włożonej w przygotowanie tej konferencji, a szczególnie za wysiłek podejmowany na rzecz badań nad Polonią i duszpasterstwem polonijnym oraz życzyć owocnych obrad. Osobiście czuję się bardzo zaszczycona, że mogę reprezentować naszą instytucję, najstarszą Polską Misję Katolicką na świecie, założoną przez osoby świeckie 178 lat temu. Gdzie byli Polacy, tam zawsze towarzyszył im kapłan. Dziękujemy Panu Bogu i Kościołowi polskiemu za troskę o emigrantów polskich we Francji. Dzisiaj w ramach Polskiej Misji Katolickiej we Francji pracuje 118 kapłanów w 96 placówkach porozrzucanych po całej Francji, a ośrodki pielgrzymkowo-rekolekcyjne w Lourdes, La Ferté sous Jouarre, La Ferté Imbault czy na Korsyce przyjmują i oczekują na naszych rodaków z Polski. Szczęść Boże".

Słowa pozdrowienia skierowała do przybyłych gości gospodyni miejsca, dyrektor Biblioteki Uniwersyteckiej KUL mgr Barbara Zezula: „W imieniu swoim, moich zastępców i bibliotekarzy Biblioteki Uniwersyteckiej KUL serdecznie chcę powitać wszystkich znamienitych gości, którzy przybyli z bliska i daleka, z różnych ośrodków w całym kraju, bardziej i mniej znanych. Propozycja zorganizowania konferencji naukowej poświęconej problematyce polonijnej w Bibliotece KUL ucieszyła mnie z kilku powodów. Po pierwsze, Biblioteka Uniwersytecka i Ośrodek Badań nad Polonią sąsiadują ze sobą i Ośrodek korzysta z literatury tutaj zgromadzonej. Po drugie, nie ma lepszego miejsca, by mówić o tych kwestiach niż ta Biblioteka, którą założyli Polacy, Polonia petersburska, jeszcze zanim powstał nasz Uniwersytet. Kolejny powód to księgozbiór, gdyż zbiory biblioteczne są bogactwem, z których korzysta wiele osób, zapewne również Państwo, którzy zajmujecie się problematyką i działalnością Polaków na całym świecie. Nasza Biblioteka jest drugą po Bibliotece Narodowej, która ma bogate zbiory emigracyjne 
po II wojnie światowej. Życzę Państwu wielu dobrych chwil w Bibliotece, wielu doświadczeń i ogromnej wiedzy, jaką Państwo wyniosą z tej konferencji”.

Krótkie przemówienie wygłosił dyrektor Ośrodka Badań nad Polonią i Duszpasterstwem Polonijnym KUL dr hab. Tomasz Panfil. Pozdrowił on obecnych od Prorektor Uniwersytetu ds. Promocji i Współpracy z Zagranicą dr hab. Urszuli Paprockiej-Piotrowskiej, której obowiązki służbowe nie pozwoliły na obecność na konferencji. Zaznaczył także: „Jest to dla nas wielki zaszczyt gościć zgromadzonych tu najwybitniejszych badaczy Polonii. Myślę, że rzadko się zdarza spotkać taki zespół ludzi w jednym czasie i jednym miejscu. Waszą obecność, Szanowni Państwo, uważam za wielki sukces. Chciałbym też wskazać na ojca tego sukcesu, którym jest ks. dr Sławomir Zych. Taka inicjatywa i taka szlachetna praca, jaką on wykonał, to tylko jego zasługa".

Krótką mowę skierował do uczestników spotkania również ks. prał. mgr Jan Prucnal, kustosz sanktuarium Matki Bożej Sokołowskiej i mecenas konferencji: „Stosunkowo niedawno, gdyż 8 czerwca ubiegłego roku, odbyła się w Sokołowie Małopolskim koronacja łaskami słynącego obrazu Matki Bożej Królowej Świata, która nazywana jest Opiekunką Ludzkich Dróg². Było to wielkie wydarzenie dla miasteczka i regionu, ale także dla całej diecezji rzeszowskiej. Przygotowywaliśmy się bezpośrednio do tego wydarzenia przez ostatnie dziewięć lat, chociaż przygotowania wcześniejsze miały miejsce już w latach 70 . i 80 . XX wieku. Zawsze towarzyszy nam Matka Boża Opiekunka Ludzkich Dróg w wymiarze przemieszczania się do różnych miejsc w kraju i poza granicą, ale także na naszych drogach duchowych. Wszyscy potrzebujemy Bożej pomocy i dlatego przyzywamy orędownictwa Matki Najświętszej. Ona jest Tą, która jest nam bliska. Gdy odbywamy podróż, wtedy się Jej powierzamy. Dzieje się to również, kiedy podejmujemy decyzje, które rzutują na nasze dalsze losy. Także ci, którzy emigrowali do różnych krajów z terenu Sokołowa i okolicy, powierzali się opiece Bogarodzicy. Jej obecność w tym wizerunku w Sokołowie jest dawna, sięga końca XVII wieku. Zaznaczała tę obecność tym, że skupiała przy sobie wiernych nie tylko $\mathrm{z}$ terenu dawnej diecezji przemyskiej, ale też archidiecezji krakowskiej. Cieszę się bardzo, że konferencji poświęconej duszpasterstwu emigrantów towarzyszy Matka Najświętsza w tym wizerunku. Jest to także pomnażanie chwały Matki Bożej. Życzę wszystkim na tej konferencji głębokich przeżyć i ubogacenia umysłów. Szczęść Boże!”.

Ks. dr Sławomir Zych przytoczył ponadto słowa z okolicznościowego pisma skierowanego do organizatorów i uczestników konferencji przez burmistrza Sokołowa Małopolskiego Andrzeja Ożoga. Pozdrawiając obecnych, włodarz sokołowski zaznaczył: „Wyrażam słowa uznania za wszelkie działania podejmowane w celu zgłębienia wiedzy o Polonii i duszpasterstwie polonijnym. Polska emigracja to temat ciągle żywy, a w dzisiejszych czasach wręcz społeczny problem. Emigracja Polaków związana jest bardzo z naszą burzliwą historią. Po wielkich

${ }^{2}$ Por. E. Kłeczek-Walicka, Uroczystości koronacyjne obrazu Matki Bożej Opiekunki Ludzkich Dróg, „Almanach Ziemi Sokołowskiej” (dalej: AZS), 1 (2014) s. 3-5; B. Walicki, S. Zych, Koronacja obrazu Matki Bożej Opiekunki Ludzkich Dróg w Sokołowie Małopolskim, „Studia Polonijne”, 34 (2013) s. 192-197. 
powstaniach XIX wieku emigracja spowodowana była terrorem na terenach zaborów. Była też wyrazem sprzeciwu wobec podporządkowania Polski obcym mocarstwom. Na przełomie XIX i XX wieku przyczyną emigracji było przeludnienie. Polscy chłopi wyjeżdżali głównie do Stanów Zjednoczonych, Kanady i Brazylii. W miastach także brakowało pracy, co zmusiło robotników do wyjazdu do Belgii, Francji czy Niemiec. Po roku 1939 emigracja wiązała się głównie z przymusowymi wysiedleniami. Po wojnie Polska znalazła się w strefie wpływów ZSRR, co dla wielu Polaków oznaczało emigrację polityczną. Lata 80. XX wieku to czas emigracji «za chlebem», a także z powodów politycznych. Po roku 89. Polska zaczęła odbudowę po latach zastoju. Wielu Polaków rozczarowanych rezultatami przemian wyjechało z kraju. Kolejną falę emigracji przeżył nasz kraj po wstąpieniu do Unii Europejskiej. Otwarcie granic, a także trudna sytuacja na rynku pracy spowodowała, że bardzo wielu Polaków, zwłaszcza młodych wyemigrowało w celach zarobkowych głównie do Wielkiej Brytanii i Irlandii. Wśród emigracji jest wielu mieszkańców naszej gminy, dlatego Sanktuarium Matki Bożej Królowej Świata - Opiekunki Ludzkich Dróg jest szczególnym miejscem modlitwy za nich".

Pierwszej części konferencji przewodniczył ks. prał. dr Roman Nir z Instytutu Historii i Archiwistyki Polonijnej w Chicago. Referaty zainaugurowała prof. dr hab. Krystyna Romaniszyn z Uniwersytetu Jagiellońskiego z wykładem Dorobek i nowe wyzwania $w$ dziedzinie metodologii badań migracyjnych. Następnie ks. dr Adam Romejko z Uniwersytetu Gdańskiego wygłosił referat Teoria mimetyczna jako metoda w badaniach polonijnych na przyktadzie Wielkiej Brytanii. Ks. dr hab. Józef Szymański z Włocławka spróbował z kolei zdefiniować i przeanalizować sam termin duszpasterstwo polonijne. Mgr Sylwia Patyra-Pytka, reprezentująca Bibliotekę Uniwersytecką KUL, nakreśliła specyfikę współpracy tej instytucji z Polonią. Posiłkując się prezentacją multimedialną, skupiła się zwłaszcza na istniejących problemach i perspektywach. Po niej wystąpił kierownik Miejskiej i Gminnej Biblioteki Publicznej w Sokołowie Małopolskim dr Bartosz Walicki. Korzystając z pokazu slajdów, ukazał sanktuarium Matki Bożej Królowej Świata - Opiekunki Ludzkich Dróg w Sokołowie Małopolskim jako miejsce modlitwy za emigrantów i refleksji naukowej nad Polonią. Pierwszą część konferencji zamknął ks. dr Roman Nir, który przedstawił inicjatywy badawcze i wydawnicze dotyczące Polonii i polskiej emigracji Stowarzyszenia Naukowego „Polska w Świecie”; był to temat opracowany wspólnie z dr Krzysztofem Wasilewskim z Wojewódzkiej i Miejskiej Biblioteki Publicznej im. Zbigniewa Herberta w Gorzowie Wielkopolskim.

Po przerwie na kawę miała miejsce druga sesja konferencyjna. Nad jej porządkiem czuwał dr hab. Tomasz Panfil. Sesję otworzył prof. dr hab. Andrzej Chodubski z Uniwersytetu Gdańskiego, który przybliżył badania nad Polonią na Kaukazie. Później prof. dr hab. Jacek Knopek z Uniwersytetu Mikołaja Kopernika w Toruniu wystąpił z tematem Diaspora polska i duszpasterstwo polonijne w Afryce. Specyfika badań i dokonania środowisk naukowych. Kolejno dyrektor Instytutu Duszpasterstwa Emigracyjnego im. Kard. Augusta Hlonda w Poznaniu ks. dr Wiesław Wójcik TChr zaprezentował referat o nowej fali emigracji pol- 
skiej w Unii Europejskiej. Dr Edward Gigilewicz z Instytutu Leksykografii KUL zapoznał słuchaczy z problematyką polonijną w „Encyklopedii Katolickiej”. Po nim głos zabrała Weronika Gigilewicz, również reprezentującą tę lubelską uczelnię. Odwołując się do prezentacji multimedialnej, postarała się zarysować temat Polonia $w$ sieci. Ożywiona dyskusja nad wysłuchanymi treściami trwała podczas posiłku przygotowanego w stołówce konwiktu księży studentów KUL.

Trzeciej sesji, po przerwie obiadowej, przewodniczył ks. prof. dr hab. Józef Wołczański z Uniwersytetu Papieskiego Jana Pawła II w Krakowie. Najpierw ks. prof. dr hab. Dominik Zamiatała CMF z Uniwersytetu Kardynała Stefana Wyszyńskiego w Warszawie zajął się problematyką duszpasterstwa polonijnego w latach 1945-1989, w dokumentach Urzędu do Spraw Wyznań, znajdujących się w zasobie archiwalnym Archiwum Akt Nowych w Warszawie. Po nim dr Jerzy Kuzicki z Uniwersytetu Rzeszowskiego podjął temat specyfiki badań nad duchowieństwem Wielkiej Emigracji w latach 1831-1863. Kolejno o. dr Marian Brudzisz CSsR z Krakowa ukazał stan badań nad dziejami Polskiej Misji Katolickiej we Francji założonej w 1922 roku. Ks. dr Roman Nir zainteresował słuchaczy dokumentacją źródłową do dziejów parafii polonijnych w archiwach amerykańskich. Dyskusje na powyższe tematy zebrani podjęli w kuluarach podczas drugiej przerwy na kawę.

Ostatniej, czwartej sesji przewodniczył dr Edward Gigilewicz. Mgr Daniel Kiper z Ośrodka Archiwów, Bibliotek i Muzeów Kościelnych KUL przeprowadził analizę statystyczną czasopiśmiennictwa polskiego w Stanach Zjednoczonych z przełomu XIX/XX wieku. Następnie dr Witalij Rosowski z Ośrodka Badań nad Polonią i Duszpasterstwem Polonijnym KUL przedstawił problematykę badań naukowych podejmowanych na łamach „Studiów Polonijnych”. Kolejno ks. prof. dr hab. Stanisław Piech z Uniwersytetu Papieskiego Jana Pawła II w Krakowie zajął się tematem kształcenia księży polskich w wiedeńskich instytutach teologicznych i na Uniwersytecie Wiedeńskim w XIX i na początku XX stulecia (do 1918) wraz z posługą duszpasterską tych studentów wśród tamtejszej Polonii. Dr Irena Wodzianowska z Instytutu Historii KUL omówiła źródła archiwalne do dziejów Rzymskokatolickiej Akademii Duchownej w Petersburgu. Głos zabrał też ks. prof. dr hab. Józef Wołczański, który przedstawił specyfikę badań i źródła do dziejów duszpasterstwa Kościoła rzymskokatolickiego po 1945 roku na dawnych Kresach Południowo-Wschodnich Rzeczpospolitej. Dr Robert Zapart z Uniwersytetu Rzeszowskiego zaprezentował referat Status bpa polowego WP Józefa Gawliny i jego relacje z władzami RP na Uchodźstwie w latach 1939-1945 -źródta i materialy. Ks. prof. dr hab. Waldemar W. Żurek SDB, dyrektor Ośrodka Archiwów, Bibliotek i Muzeów Kościelnych KUL, zapoznał z kwerendą naukową i warsztatem badawczym przy zgłębianiu tematu działalności salezjanów na terenach byłego ZSRR po 1945 roku. Ks. dr Stanisław Tylus SAC, reprezentujący Wyższe Seminarium Duchowne Stowarzyszenia Apostolstwa Katolickiego w Ołtarzewie, wygłosił referat Pallotyni na rzecz Polonii - stan badań. Po nim dr hab. Tomasz Panfil przybliżył źródła zagraniczne do duszpasterskiej posługi ks. gen. Witolda Kiedrowskiego (1912-2012). Sesję zamknęło krótkie wystąpienie ks. prof. dr. hab. Edwarda Walewandera z Instytutu Pedagogiki KUL na temat 
wybranych aspektów badań nad Polonią. Dodać trzeba, że osobne tematy na konferencję opracowali pracownicy Ośrodka Badań nad Polonią i Duszpasterstwem Polonijnym KUL: ks. dr Sławomir Zych i dr Paweł Janowski. Pierwszy przygotował referat Kronika parafialna jako źródło do dziejów emigracji (na przykładzie Osieka Jasielskiego), zaś drugi referat Czasopismo polonijne jako kategoria źródta historycznego. Aspekty metodologiczne.

Ważnym elementem spotkania naukowego było wręczenie medali koronacyjnych sanktuarium Matki Bożej Sokołowskiej. Medale takie wybiło Towarzystwo Miłośników Ziemi Sokołowskiej z okazji koronacji wizerunku Opiekunki Ludzkich Dróg w dniu 8 czerwca 2013 r. Odznaczenia te przyznali: kustosz tego ośrodka kultu maryjnego ks. mgr Jan Prucnal, opiekun naukowy sanktuarium z ramienia Biskupa Rzeszowskiego ks. dr Sławomir Zych oraz prezes Towarzystwa Miłośników Ziemi Sokołowskiej dr Bartosz Walicki³.

Medale stanowiły wyraz uhonorowania osób szczególnie zasłużonych dla duszpasterstwa polonijnego, badań nad Polonią, popularyzacji dziedzictwa kulturowego Polonii oraz badań nad dziejami Polaków na Wschodzie. Otrzymali je: dr Anna Łucka, prof. dr hab. Krystyna Romaniszyn, prof. dr hab. Andrzej Chodubski, dr hab. Jacek Knopek, ks. prał. dr Roman Nir, ks. dr hab. Józef Szymański, ks. prof. dr hab. Edward Walewander, ks. dr hab. Józef Wołczański, ks. dr Wiesław Wójcik TChr i ks. dr hab. Waldemar Witold Żurek SDB, a także Redakcja „Encyklopedii Katolickiej”. Same medale ufundował ks. dr Sławomir Zych. Wręczenia dyplomów i medali dokonał natomiast kustosz ks. Jan Prucnal ${ }^{4}$.

Podsumowaniem konferencji była krótka dyskusja. Spotkanie naukowe zamknął dr hab. Tomasz Panfil. Przyznał on m.in. „Wszyscy jesteśmy pełni wrażeń i pełni wiedzy po wysłuchaniu tylu niezwykle ciekawych referatów wygłoszonych przez kompetentnych badaczy tematu. Rzadko kiedy udaje się wysłuchać w tak krótkim czasie tak dużo treści. Przy tej okazji dziękuję ks. dr. Sławomirowi Zychowi za olbrzymi trud i wkład pracy w przygotowanie tej konferencji. Wszystkim dziękuję za miłą obecność, a prelegentom za podzielenie się z nami swoją wiedzą". Dyskusja na tematy przedstawione podczas konferencji była kontynuowana w luźnej atmosferze podczas kolacji w stołówce konwiktu księży studentów KUL. Wspomnieć na koniec należy, że fundatorem obiadu i kolacji był kustosz sanktuarium sokołowskiego ks. Jan Prucnal ${ }^{5}$.

${ }^{3}$ Por. P. Sidor, Medal koronacyjny, „U Sokołowskiej Pani. Jednodniówka wydana z okazji koronacji łaskami słynącego obrazu Matki Bożej Królowej Świata - Opiekunki Ludzkich Dróg”, 8 czerwca 2013 r., s. 42.

${ }^{4}$ B. Walicki, Uroczyste wręczenie medali koronacyjnych na KUL, AZS, 2014, nr 1, s. 32.

${ }^{5}$ Por. M. Nabożny, $W$ kręgu badań nad Polonia $i$ duszpasterstwem polonijnym, „Niedziela Rzeszowska”, 22 (2014) s. VI; tegoż, KUL: W kręgu badań nad Polonia, „Dziennik Polski”, 28 V 2014, s. 61; B. Walicki, S. Zych, Naukowa refleksja nad Polonia i duszpasterstwem polonijnym, AZS, 2014, nr 1, s. 29-31; tychże, Konferencja , $W$ kręgu badań nad Polonia i duszpasterstwem polonijnym”, „Rocznik Sokołowski”, 11 (2014) [w druku]. 